\title{
On the Inter-Textuality Theory of Novels and Films
}

\author{
J. He, Y. Deng \\ Nanchang University, Nanchang, Jiangxi, China
}

\begin{abstract}
Novels, films, TV shows that three different forms of art, while each have their own artistic characteristics, language system and the text characteristic, however, the same origin of art, they are connected. Novels and dramas inter-textuality are based on the novel text and narrative characteristics of the similarities and differences between the film and television.
\end{abstract}

KEYWORD: Novel; Film; Inter-textuality; Art; Characteristic; Language System

\section{INTRODUCTION}

The achievements of Chinese film and television creation cannot leave the nourishing of literature. Y.M. Zhang once said: "China has a lot of good films, first of all, thanks to the Chinese writers' good fiction because they provide the possibility of recreation for the films. If remove these novels, most of China's film couldn't exist.'[1] Today, under the modern science and technology, it is the fact that the film with powerful audio and visual impact and the young TV shows with incomparable permeation are overwhelming in modern era and the commercial society. Image has a solid position in the culture symbol, however, the literature as a representative of the traditional art has been forced tor under declining for survival or for material benefits and so on. The book of the film and television are becoming more and more popular as the adaptation of the film and television. First, the film and television were produced and then adaptation of the novels with the same name were came out too, such as "never close eyes", Haiyan's series of TV shows as "Jade of Kuanyin", "the door of the Mansion", "House of Flying Daggers", "Curse of the Golden Flower", "The Banquet" , "Cell Phone", etc. The audience appreciates them with the applause, sigh, admiration and anxiety. But no matter what attitude you take, the relation is becoming more and more interact between the literature and the film and television. The relations between the two are strengthening or weakening? Is a mutually beneficial for both or not? These are all worthy of our considering.

\section{DIFFERENCE AND CONNECTION BETWEEN NOVELS AND FILMS}

From novel to television or from television to novel are the transformation of narrative media and the most important change of narrative media is the conversion of narrative language. The narrative language is the symbol system which used to express information. Through the narrative language, works can communicate with the outside world. Novel image text and TV drama in the narrative language is very different. The novel is narrated by language, written language is the essential characteristic of novel. The word is the tiniest unit of language, the novel constitutes ideographic written language system, written language is abstract, but seen from the Chinese ancient hieroglyphic language, and words should be closely linked with the "picture". Accompanied by the birth of words, especially after the invention of printing, in the long course of years, written language has formed a set of precise rules ideographic in humans' long-term accumulation of rational thought becoming the shell of human thinking. So, although the medium of speech is an element in the form, it has enormous potential of meaning, words and narrative can create meaning, language combinations highlights works symbolic charm, blank the fuzziness, uncertainty and meaning, and bringing language endless enjoyment. Eileen Chang used to say: "how could a scholar willingly and gladly keep in the 'literary' inside? I say it was because of the charm of text".[2]

Film and television use sound and picture to tell the story, but pay more attention to image, known as audio-visual art. German philosopher Cassirer said: 
"In a sense, all art is language, but they are only a certain sense of language, they are not text symbols of language, but intuition symbols".[3] Lens is the smallest unit of film language. It is representational. Griffith's biggest contribution to the film was created lens as the smallest unit of film language, which laid the foundation of the movie as an independent art. Movies with a special focus on footage. The original film is silent, the silent era from 1895 to 1927 when the first VCR "the jazz singer" was born, leaving too much glory, so that the transition from silent film to sound film, whether in practice or theory description, has experienced a long lips gun heated dispute! Until Bergman also bluntly said, movie has nothing to do with literature. Of course, I think this is a kind of backward, text and image of schools, Su Shi's evaluation of Wang Wei's poetry was very incisive: "poems have painting, painting in poetry".

For the function of literature and television drama, although that "literature is profound, is for people to thinking; film is facile and for human entertainment" like a foregone conclusion, however this is no doubt extreme words. Indeed, the written language as a symbolic form of human communication and expression of emotion, after thousands of years, literature is subtle deep, because of indirect feeling, it gives the reader a lot of imagination and a long aftertaste, as aesthetic enjoyment of reading and writing already become a human collective unconscious. However, the rapid development of the hundred-year history of the film, its film ideographic language feature can also not to be underestimated. The rich possibilities of film language can be fully taped and unleashed maximize, although the drama of the lens is slightly inferior than the expression of film camera, as the development of high-tech and the most penetration of mass media, "latecomers" trend also found its television language. George Bruce East, said it well: "The most fundamental point of art of novel and film is let people 'seen', and the way they let people seen is totally different", "People can see by naked eyes, or you can look through the mind's imagination. And the difference between the view of sight and the concept image caused by ideological reflects the most fundamental differences between the novel and film".[4]

\section{THE SAME STORY, DIFFERENT NARRATIVE}

A novel that widely concerned means a lot of people read it. An infamous novel attracted the readers, the commentators will write a comment, the director will direct a film or TV show. Besides the commercial motives, the creator's impulse is from the recreation of reading. At the same time, the writer will create more after reading the novels' wonderful description. On this condition, the write will turn the abstract words into visual image. As a film or TV show becomes famous, the book which is about the film or TV show will available in order to seize more opportunity. However, the novel's author is often the writer himself, during this process, which is about novel narrative. The psychological description, scenery description, philosophic thinking and so on which was abandoned by the film or TV shows will be wrote in the novels with the novel's narrative techniques, rather than simply added.

In fact, both novels, movies and TV shows, their aesthetic function are consistent, that is to show the human emotional and aesthetic experience, let people know self, know life and understand the meaning of life, thus obtain aesthetic pleasure, meet the spiritual freedom, implement requirements of self-affirmation in spirit, they are human spiritual sustenance. For the creator or the audience, some of them is high level of behavior which consciously and active, other is lower level of behavior which involuntary and passive .Today, if we still rely on novels, movies, TV shows and their audience to distinguish between elite and civilian, elegance and lowbrow, depth and flat, reason and sensibility, that doesn't keep pace with The Times.

Nothing is absolutely perfect. Novels may be elegant or vulgar. TV films can also be divided as excellent, fair and poor. A bad novel is just as hateful as an inferior TV film. People will remember and be touched by elegant expressions for a life time. Language in TV films often impresses you by fantastic montage, Pip, flashback, overprint, depthof-field shots in various levels or close-ups of the eye. For example, The step Odessa of Eisenstein, the light and shadow in The Seventh Seal by Bergman, John Woo's aesthetics of violence. The essence of language determines its limitation. It helps the author deliver his message, but sometimes it hides the information. Therefore, language is both the bridge and the wall. As an old saying goes, "seeing believes". TV films make novels vivid through strong sense of pictures, montage effects, Synchronization and dislocation of sound and picture, description of events in past, present and future, as well as multi-display of space at the same time, which is a great inspiration and encouragement for novelists. The narration of film language provides the new angle and new reference to that of novels. Naturally, the written language can not be replaced by the images completely or terminated for its own charm, elegance and aesthetic connotation. TV films are always influenced by literature. David Griffith once pointed out that we can shoot as long as Dickens can write.

The same story, different narrator to tell it in a different way; The same story in different media 
such as oral narratives, written narrative, audiovisual media (image) of narrative and media mix have different narrative. The founder of the Film adaptation theory, Bella Balazs said: "only we put the 'content' and 'form' as a generalized understanding, we can accept both content (or material) to form the theory (art), at the same time that can give the same material in different forms.[5] 'Content' is not only refers to material, action, plot, story and theme as we used to understand, while the 'form' refers to the 'art form'. In fact, may be the subject of the novel story adapted into a perfect stage the script or movie script (the so-called perfect, that is, form the content is suitable for each other) why have this possible? Because although the two works have the same subject matter or story, their content is different, it is the different content that is suitable for the form that changed because of the adaptation." According to the similarity of novels and dramas, contributed to the commensurability between each other; In fact, the differences between each other more contributed to the mutual transformation of the medium.

For the combination of literature and film and television, of course, we can't just narrowly understand as the use of film and television adaptation of literary works or "Film-TV corresponding books", this is just a combination of one of the important forms. Generalized refers to the combination of literature, film, television, the three different art forms from each other, although they have their own artistic characteristics, language system and the text characteristic, however, art the same, they are connected to, both fiction and film and television play, whether by word symbol or image symbol, are using narrative to imaginary or create a virtual space and time, story, plot, characters, themes, and the space and time feeling, rhythm and so on are indispensable to fiction, film and television play art element, to satisfy the audience's expectation field of vision, so as to realize the audience aesthetic sense of the real world to reproduce or compensation.

\section{CONCLUSIONS}

The inter-textuality of novels and dramas, based on the narrative features of similarities and differences between the novel text and the film and television play. Inter-textuality includes the combination of the space relationship between the texts and also includes the text and the original text in time on paradigmatic relations. "Special contribution of inter-textuality is to make the old works constantly to enter a new cycle.’'[6]

\section{REFERENCES}

[1] Mo Chen. On Zhang Yimou's Films. China Film Publishing House, 1995, 249

[2] Eileen Chang. Eileen Chang Anthology (fourth volume). Anhui literature and Art Publishing House, 1992, 85-86.

[3] Cassirer. The Language and the Myth. The Joint Publishing Company, Ltd, 1988, 96.

[4] George Bruce East. From Novel to Film. China Film Press, 1981, 1-2.

[5] Bella Balazs. Cinema Aesthetics. China Film Publishing House, 1988, 148-269.

[6] Tiphaine Samoyault., translated by Wei Shao. L'intertextualité, Tianjin People's Publishing House, 2003, 114. 